\title{
ДИНАМІКА ІМУНОЛОГІЧНИХ ПОКАЗНИКІВ КРОВІ СОБАК ЗА РІЗНИХ МЕТОДІВ ЛІКУВАННЯ РАН
}

\section{Рецензент - кандидат ветеринарних наук О. О. Міланко}

\begin{abstract}
Наведено динаміку імунологічних показників за різних методів лікування ран у собак. Доведено, щзо місиеве застосування препаратів гіалуронової кислоти та трифузолу у комплексному лікуванні гнійних ран у собак стимулює загоєння шляхом прискорення репаративних процесів. Встановлено більш швидке відновлення показників специфічної та неспецифічної резистентності організму в фазу регенерачії та проліферачї ранового процесу: підвищення вмісту T і В-лімфоцитів, імуноре-

гуляторного індексу, фагоцитарного числа, а також НСТ-тесту.
\end{abstract}

Ключові слова: собаки, рани, лімфочити, імуноглобуліни, фалоцитоз.

Постановка проблеми. Процес загоєння ран $\epsilon$ одним 3 основних механізмів захисту організму від травм. Проте існують обставини, коли цей фізіологічний процес порушується - й репарація ран відбувається повільно. Тому пошуки нових методів раціональної патогенетичної терапії залишаються важливою проблемою сучасної хірургіiі.

Аналіз основних досліджень і публікацій, у яких започатковано розв'язання проблеми. Швидкість загоєння рани залежить від характеру травми, кількості нежиттєздатних тканин та вірулентності мікрофлори, що іiі контамінувала. Показники імунобіологічної реактивності організму - фактори, що визначають розвиток гнійно-запальних процесів. Однак під час лікування гнійних хірургічних захворювань із використанням антибіотиків спостерігають зниження показників імунітету, особливо у тварин із гіпоергічним типом реактивності. Тому застосування імуностимулювальної терапії $\epsilon$ патогенетично необхідним компонентом комплексного лікування ран [1].

Встановлено, що похідні триазолу мають імуностимулювальну, гепатопротекторну, протизапальну та антиоксидантну активність. Препарати стимулюють еритро- і лейкопоетичні функції.
Крім цього вони мають бактерицидні й фунгіцидні властивості. Використання хірургічної обробки та внутрішньом'язових ін'єкцій трифузолу дає змогу скоротити терміни загоєння ран [2].

Мета - встановити імунологічні показники крові за різних методів лікування ран у собак.

Завдання: застосувати препарати гіалуронової кислоти та трифузолу у комплексному лікуванні гнійних ран; визначити вміст Т і В-лімфоцитів, імунорегуляторного індексу, фагоцитарного числа, а також НСТ-тесту.

Матеріали і методи досліджень. Дослідження проводили на безпородних собаках із шкірном'язовими ранами площею 50-60 $\mathrm{cm}^{2}$. Перші п'ять діб щоденно проводили ревізію ран і місцеву механічну обробку, застосували курс антибактеріальної терапії (15\% амоксициклін, INVESA). Далі тварин поділили на дві групи. Для лікування тварин першої групи використали мазь метилурацил із мірамістином та додаванням у неї $1 \%$ гіалуронової кислоти і $1 \%$ ВПК108 (трифузол). Мазь використовували у вигляді поверхневих аплікацій раз на добу. Друга група слугувала контролем (застосували мазь метилурацил із мірамістином). У тварин обох піддослідних груп відбирали кров до початку експерименту, а також на 6-у, 12-у і 24-у добу після поранення.

Мазь метилурацил із мірамістином (ЗАТ фармацевтична фірма «Дарниця», Україна) містить метилурацил, який стимулює метаболічні процеси, та мірамістин - катіонний антисептик. Трифузол - похідне 1,2,4-тріазолу, має антиоксидантні, гепатопротекторні, протизапальні властивості. Рекомендується для лікування локалізованих запально-гнійних процесів [2].

Гіалуронова кислота - несульфатований глікозаміноглікан, що входить до складу сполучної, епітеліальної й нервової тканин. Для досліджень була використана гіалуронова кислота бактеріального походження (Streptococcus equi) фірми «Fluka» (Швейцарія).

\section{* Науковий керівник - доктор ветеринарних наук, професор В. Й. Іздепський}




\section{СТОРІНКА МОЛОДОГО ВЧЕНОГО}

Кількість Т- і В-лімфоцитів визначали методом фенотипування у тестах розеткоутворення 3 частками, вкритими моноклональними антитілами. Для оцінки функціонального стану В-системи імунітету у сироватці крові визначали вміст трьох основних класів імуноглобулінів - M, G, А - методом радіальної імунодифузії в агарі (за Г. Манчині). Фагоцитарну активність визначали за методиками А. С. Прилуцкого. Окиснювально-відновлювальну здатність нейтрофільних гранулоцитів оцінювали в НСТ-тесті [3].

Результати досліджень. Клінічним обстеженням встановлено, що за застосування в II і III фазах ранового процесу мазі метилурацил із мірімістином із додаванням гіалуронової кислоти $\mathrm{i}$ ВПК-108 відмічали прискорення росту грануляційної тканини та крайової епітелізації. У тварин першої групи загоєння ран реєстрували на 2325-у, другої - на 27-29-у добу.

Імунний статус оцінювали за характеристикою функціональної активності Т- і В-лімфоцитів з урахуванням їх абсолютного та відносного вмісту у крові. На дванадцяту добу досліджень у тварин першої групи вірогідно зросла кількість лімфоцитів і становила 4344,5 243,7 кл/мкл, що вище, ніж на шосту добу експерименту, в 1,8 разу й вище від вихідного показника на 64,3 \% (p<0,01). Рівень Т-лімфоцитів становив 41,83 $\pm 1,49 \%$, що вище, ніж попередній показник, на 10,1\%; до того ж $\ddot{1 x}$ абсолютна кількість зросла до $1816,5 \pm 116,04$ кл/мкл, що вдвічі більше порівняно $з$ шостою добою досліджень.

У тварин другої контрольної групи на дванадцяту добу досліджень також реєстрували зростання кількості лімфоцитів, проте менш виражене, ніж у першій. Даний показник становив 2684,33 $\pm 346,79$ кл/мкл, що вище від попереднього значення на $16,8 \%$, однак нижче, ніж у тварин першої групи, в 1,6 разу $(\mathrm{p}<0,05)$. Відсотко-

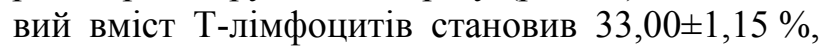
що менше від аналогічного показника у першій піддослідній групі на 21,1\% $(\mathrm{p}<0,05)$. Вміст регуляторних субпопуляцій становив $\mathrm{CD} 4+-$ $29,83 \pm 0,91 \%$ та CD8+ лімфоцитів - 19,83 $\pm 0,91 \%$. Імунорегуляторний індекс - 1,51 $\pm 0,08$, що нижче, ніж у собак першої групи, на 20,9\% $\%$ (p<0,01).

Абсолютний і відносний лімфоцитоз розвивається після передачі інформації про антиген лімфоцитам від антигенпрезентуючих клітин.

Перехід імунної відповіді в лімфоцитарну фазу клінічно виявляється зменшенням клінічних проявів запалення - загальних (гіпертермія, інтоксикація) i місцевих (набряк, почервоніння, біль). Лімфоцитарні реакції стимулюють факто- ри природної резистентності, внаслідок чого імунна відповідь стає більш ефективною. У період розвитку запальних реакцій імунорегуляторний індекс сягає високих показників за рахунок значного відсоткового вмісту Т-хелперів (CD4+ Т-клітин). У період регенерації IPI зменшується у зв'язку з наростанням рівня CD8+ T-клітин (кілерів).

На 24-у добу після початку досліджень у тварин обох груп реєстрували тенденцію до зниження вмісту всіх субпопуляцій лімфоцитів. Абсолютна кількість лімфоцитів у собак першої групи становила 2807,0 142,51 кл/мкл, що нижче від попереднього значення в 1,5 разу, проте вище, ніж у тварин другої групи, на 13,9\% $(\mathrm{p}<0,05)$. У цей період зазнав зниження відсотко-

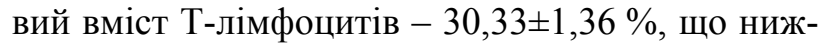
че на $27,5 \%$, ніж показник на дванадцяту добу досліджень і на 25,7 \% менше вихідного значення. Їх абсолютна кількість становила $849,83 \pm 50,36$ кл/мкл, що на 18,3\% вище, ніж у тварин другої групи. Зниження CD3+ лімфоцитів відбувалося переважно за рахунок Т-хелперів даний показник становив 26,67\%, що менше попереднього значення на 35,2\%. Рівень CD8+

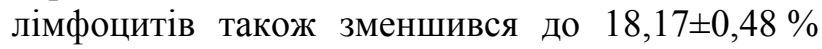
порівняно 3 вихідним показником - 27,67\% $(\mathrm{p}<0,001)$. Імунорегуляторний індекс становив $1,47 \pm 0,05$.

У тварин другої контрольної групи на 24-у добу досліджень також реєстрували знижений рівень лімфоцитів - 2464,67士56,01 кл/мкл, що вірогідно нижче, ніж у собак першої групи, на $13,9 \%(\mathrm{p}<0,05)$. Відсотковий вміст Т-лімфоцитів

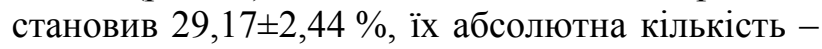
$718,5 \pm 62,97$ кл/мкл. Відбулися також зміни серед субпопуляцій CD3+ лімфоцитів: вміст Т-хелперів зменшився до $23,17 \pm 1,14 \%$, що менше вихідного показника на 52,4 \% і вірогідно нижче, ніж у тварин першої піддослідної групи на 13,1%. На противагу, відсоток CD8+ лімфоцитів збільшився й становив 20,5 $\pm 0,8 \%$, що вище, ніж аналогічний показник у собак першої групи на 12,8 \% $(\mathrm{p}<0,05)$. За рахунок цього зменшився імунорегуляторний індекс - 1,14 $\pm 0,06$ і був вірогідно нижчим, ніж у тварин першої групи. Така закономірність свідчить про ймовірність хронічного перебігу інфекційного процесу через неповну ерадикацію збудника.

Для кількісної оцінки ефекторної ланки клітинного імунітету визначали вміст великих гранулярних лімфоцитів (ВГЛ) - популяції клітин, до складу якої входять природні кілери. У тварин обох груп вірогідне зростання вмісту при- 
родних кілерів реєстрували на дванадцяту добу експерименту. Відповідні показники становили у тварин першої групи 17,83 $\pm 0,95$ кл/мкл, у другої - 16,17士0,87, що вище ніж перед експериментом у 1,9 та 1,8 рази ( $<<0,01$ і $\mathrm{p}<0,05$ відповідно). Подібні зміни виявляли також на 24-у добу спостережень.

Ефекторною ланкою гуморальної імунної відповіді $є$ синтез антитіл і фагоцитоз, за рахунок якого знешкоджуються сформовані імунні комплекси. Гуморальну ланку імунітету характеризують рівні CD22+-клітин (В-лімфоцитів), а також рівні імуноглобулінів різних класів (IgM, $\operatorname{IgG}, \operatorname{IgE}$, сироваткового і секреторного $\operatorname{IgA}$ ).

На дванадцяту добу експерименту у тварин першої групи вміст В-лімфоцитів становив $26,33 \pm 0,61 \%$, що вище вихідного значення на 8,9\%. Проте їх абсолютна кількість (1148,5+84,12 кл/мкл) порівняно з вихідним значенням зросла в 1,8 разу $(\mathrm{p}<0,01)$. Відсотковий вміст В-лімфоцитів у

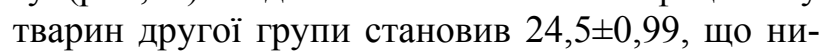
жче вихідного на 4,6\%. Абсолютне число $\mathrm{CD} 22+$ лімфоцитів - 653,5 $\pm 79,71$ кл/мкл, що менше, ніж у тварин першої групи, в 1,8 разу $(\mathrm{p}<0,05)$.

Імуноглобуліни М - це антитіла гострого періоду імунної відповіді, що синтезуються плазматичними клітинами при першому контакті 3 певним патогеном. Вони мають здатність активувати комплемент, що забезпечує реалізацію комплементзалежної цитотоксичності. Високі концентрації специфічних IgM у собак обох груп реєстрували на дванадцяту добу досліджень. У тварин першої групи - 1,2士0,02 г/л, що вище, ніж перед дослідженнями, на $36,4 \%(\mathrm{p}<0,001)$; у собак другої - 1,14 $\pm 0,02$ г/л, вище від вихідного показника на $12,9 \%(\mathrm{p}<0,05)$, проте нижче, ніж у тварин першої групи, на 5 \%. Наступними дослідженнями встановлено зниження вмісту IgМ у тварин обох груп.

Імуноглобуліни $\mathrm{G}$ - це антитіла пізньої фази імунної відповіді, вони є більш специфічними, ніж IgM; мають лише два центри зв'язування антигену й меншу молекулярну масу, тому володіють більшою проникністю до периферичних тканин. Максимальні показники на 24-у добу -

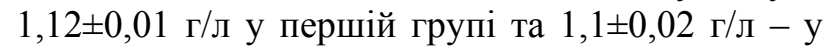
другій, що вище ніж на початку досліду на $27,3 \%(\mathrm{p}<0,001)$ та 8,9\% $(\mathrm{p}<0,05)$ відповідно. Високі рівні специфічних IgG реєстрували в період регенеративних процесів та одужання, поскільки саме цей клас антитіл продукують клітини імунної пам'яті.

Вміст імуноглобулінів А у процесі досліду за- знав неістотних коливань у тварин обох груп: у собак першої групи дані показники коливалися від 0,9 до 0,95 г/л, у другої - 0,92-1,01 г/л.

Систему природженої резистентності характеризують величина фагоцитарного числа (ФЧ) i фагоцитарного показника (ФП), а також значення НСТ-тесту. До того ж ФЧ і ФП дають можливість оцінити поглинальну активність фагоцитів, а НСТ-тест - інтенсивність «кисневого вибуху», що характеризує метаболічні процеси фагоцитуючих клітин.

Збільшення фагоцитарного показника у собак обох груп реєстрували на дванадцяту добу експерименту: у тварин першої групи до $46,83 \pm 0,91 \%$, що вище, ніж перед експериментом, на $13,7 \%(\mathrm{p}<0,05)$. У собак другої групи

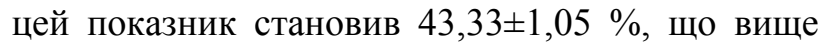
вихідного значення на $4,4 \%$, проте менше на $7,5 \%$, ніж у тварин першої групи $(\mathrm{p}<0,05)$. На 24-у добу експерименту фагоцитарний показник у собак, яким застосовували ГК і ВПК-108, залишався на високому рівні $(46,5 \pm 0,85 \%)$, що перевищувало показник другої піддослідної групи $(41,83 \pm 1,05 \%)$ на $11,2 \%(\mathrm{p}<0,01)$.

Аналогічні тенденції реєстрували в процесі аналізу динаміки фагоцитарного числа у піддослідних собак. У тварин першої групи цей показ-

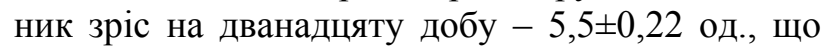
вище ніж перед дослідженням на $24 \%(\mathrm{p}<0,05)$.

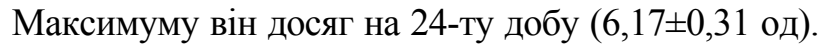
У тварин другої групи фагоцитарне число уподовж досліду було вірогідно нижчим, аніж у собак першої піддослідної групи (на 12-у добу $6,67 \pm 0,21$ од., $24-\mathrm{y}-4,67 \pm 0,33$ од.).

Тест із нітросинім тетразолісм (НСТ-тест) відображає рівень активації кисневозалежних механізмів бактерицидності фагоцитуючих клітин. Вірогідне зростання показників НСТ-тесту у тварин реєстрували на дванадцяту добу ранового процесу. У тварин першої групи він становив $1,74 \pm 0,11$, що вдвічі вище ніж перед дослідженнями $(\mathrm{p}<0,001)$. У собак другої групи даний показник також у цей період зріс до 1,46 $\pm 0,07$, що вище ніж вихідне значення у 1,8 разу $(\mathrm{p}<0,05)$. Подальшими спостереженнями встановлено зниження показників НСТ-тесту у тварин обох груп.

Підвищені показники НСТ-тесту на початкових етапах ранового процесу в обох групах вказують на зміну функціонально-метаболічної активності лейкоцитів. Зниження рівнів активності НСТ-тесту реєстрували в період регенерації та загоєння ран, тобто на 24-у добу досліджень.

Отже, імунологічні показники обох піддослід- 
них груп на шосту добу досліджень істотно не відрізнялись. У всіх тварин реєстрували вірогідне зниження CD4+ лімфоцитів, як наслідок - IPI також знизився. На 12-у добу досліджень реєстрували суттєві відмінності між показниками контрольної та дослідної груп. У тварин першої групи, яким використали для лікування ВПК-108 та ГК, абсолютний вміст лімфоцитів (зокрема Тi В-лімфоцитів) був вірогідно вищим ніж у тварин другої групи. Серед регуляторних субпопуляцій значно збільшилася частка CD4+ T-клітин, за рахунок чого зріс показник імунорегуляторного індексу. На відміну, у тварин другої групи IPI був у цей період вірогідно нижчим.

У період загоєння (24-а доба досліджень) реєстрували різницю вмісту CD8+ лімфоцитів: у тварин другої (контрольної) групи даний показник був вірогідно вищим, аніж у собак дослідної; як наслідок - імунорегуляторний індекс був нижчим. Більш низькі значення IPI у контрольних

\section{БІБЛІОГРАФІЯ}

1. Гайдюк М. Б. Обгрунтування доцільності застосування ербісолу за гнійних запальних процесів у собак / М. Б. Гайдюк, Н. М. Хомин // Науковий вісник ветеринарної медицини: 3б. наук. праць. - Біла Церква, 2010. - Вип. 4 (76). - C. 35-37.

2. Киричко Б. П. Патогенетичне обгрунтування лікування тварин із запальною хірургічною па- тварин порівняно $з$ дослідними можуть свідчити про хронічний перебіг запальних процесів.

У тварин першої групи, яких лікували з використанням ВПК-108 і ГК, реєстрували вірогідно вищі показники фагоцитарного числа й фагоцитарного показника на 12-24-у добу досліджень.

\section{Висновки:}

1. Місцеве застосування препаратів гіалуронової кислоти та трифузолу у комплексному лікуванні гнійних ран у собак стимулює загоєння ран шляхом прискорення репаративних процесів.

2. Використання трифузолу і гіалуронової кислоти сприяє відновленню показників специфічної та неспецифічної резистентності організму в фазу регенерації й проліферації (12-а доба): підвищенню вмісту Т-клітин (1816,5 $\pm 116,04$ кл/мкл), В-лімфоцитів (1148,5 $\pm 84,12$ кл/мкл), фагоцитарного показника $(46,83 \pm 0,91 \%)$, фагоцитарного числа $(5,5 \pm 0,22$ од.), а також НСТ-тесту $(1,74 \pm 0,11)$.

тологією препаратами 3 антиоксидантною дією / Б. П. Киричко : автореф. дис. ... докт. вет. наук : 16.00.05 - ветеринарна хірургія / Б. П. Киричко. K., 2010. $-36 \mathrm{c}$.

3. Лаповец̧ь Л. С. Посібник із лабораторної імунології / Л. С. Лаповець, Б. Д. Луцик. - Львів, 2002. -173 c. 